\title{
Multiple parasite introduction and host management plan: case study of lutjanid fish in the Hawaiian Archipelago
}

\author{
Matthias Vignon ${ }^{1,2, *}$, Pierre Sasal ${ }^{1,2}$, Mark C. Rigby ${ }^{3,4}$, René Galzin ${ }^{1,2}$ \\ ${ }^{1}$ Centre de Biologie et d'Ecologie Tropicale et Méditerranéenne, UMR 5244 CNRS-EPHE-UPVD, avenue Paul Alduy, \\ 66860 Perpignan Cedex, France \\ ${ }^{2}$ Centre de Recherche Insulaire et Observatoire de l'Environnement, UMS 2978 CNRS EPHE, BP 1013, 98729 Papetoai, \\ Moorea, Polynésie Française \\ ${ }^{3}$ Parsons, 2121 N California Boulevard, Suite 500, Walnut Creek, California 94596, USA \\ ${ }^{4}$ Marine Science Institute, University of California, Santa Barbara, California 93106, USA
}

\begin{abstract}
The bluestriped snapper Lutjanus kasmira and the blacktail snapper L. fulvus were deliberately introduced in the Hawaiian Archipelago from French Polynesia in the late 1950s to enhance local fisheries. These species rapidly spread all over the Windward Islands, became extremely abundant and, therefore, caused controversial environmental concerns. A comparison of the whole metazoan parasite community of L. kasmira and L. fulvus was performed between their native ranges in French Polynesia (Moorea Island in the Society Archipelago and Ua Huka in the Marquesas Islands) and their introduced range in O'ahu, Hawaii, USA. We suggest that 8 monogenean species have been introduced with L. kasmira and L. fulvus into the Hawaiian Archipelago from French Polynesia; 2 other species as well as one nematode should be referred to as cryptogenic. Moreover, experimental mortality conducted on monogeneans found in Polynesia emphasizes the inefficiency of anti-parasite treatment which was performed $50 \mathrm{yr}$ ago, explaining possible parasite introduction. Finally, we discuss the potential threat of exotic parasites to the native fish community in the Hawaiian Archipelago and conclude that the absence of co-evolved hosts prevents parasite transfer from non-indigenous to native fishes as monogeneans are highly specific.
\end{abstract}

KEY WORDS: Parasite community · Non-indigenous species · Lutjanus • Hawaii • Polynesia · Copper sulphate

Resale or republication not permitted without written consent of the publisher

\section{INTRODUCTION}

Coastal estuarine and marine systems are currently among the most heavily invaded systems in the world (Grosholz 2002) and the rate of biological invasions in those ecosystems has substantially increased in recent years (Ruiz et al. 2000). The introduction of nonindigenous animals and plants has been identified by scientists and policy makers as a major threat to biodiversity in marine ecosystems with each successive invasion having unpredictable negative consequences on the environment, economy and society (McNeely
2001, Bax et al. 2003, Pimentel et al. 2005). Ecological studies of exotic species focus primarily on how invaders directly affect particular resident species. In contrast, little is known about the indirect effects of introduced species on native communities in the wild, including how pathogens may be spread by introduced species. Among the less conspicuous effects of introduced species is the presence of accompanying parasites and diseases (e.g. bacteria, viruses, fungi) that can strike local populations and communities (Thomas et al. 1999, Horwitz \& Wilcox 2005, Hudson et al. 2006). The threat to native populations from the introduction 
of exotic parasites is well known (Dobson \& Foufopoulos 2001, Grosholz 2002, Prenter et al. 2004, BondadReantaso et al. 2005). For example, introduced parasites have decimated naïve host populations in several cases (Anderson \& May 1986, Harvell et al. 1999, Hay et al. 2004, Prenter et al. 2004). The best known example among fish is the decimation of the Aral Sea sturgeon Acipenser nudiventris by the monogenean Nitzchia sturionis. This parasite was accidentally introduced to the Aral Sea with the Caspian Sea sturgeon Huso huso in the 1930s (Dogiel \& Lutta 1937). However, parasites remain an underestimated component of total biodiversity (Luque \& Poulin 2007), usually because of their small size and cryptic way of life. Thus, the introduction of parasites in a new ecosystem is of concern in a conservational context and remains poorly studied in the wild.

The Hawaiian Islands are among the most geographically and hydrographically isolated in the world and, thus, exhibit a unique reef fish assemblage. This isolation has resulted in some major reef fish taxa being totally absent or poorly represented. Further, unlike other islands in the Indo-Pacific, the Hawaiian Islands lack reef fish species that support valuable commercial and recreational fisheries such as shallow-water groupers and snappers (Oda \& Parrish 1981, Coleman et al. 2000). Thus, in the late 1950s, the Hawaiian government introduced various reef fishes to the Hawaiian Islands from French Polynesia to enhance local fisheries.

Among the 11 species intentionally introduced from French Polynesia to the Hawaiian Islands (Randall 1987), only 5 became established (Murphy 1960, Oda \& Parrish 1981, Randall \& Kanayama 1982, Randall 1987, Randall et al. 1993a): the Marquesan sardine Sardinella marquesensis, 3 lutjanid species (blacktail snapper Lutjanus fulvus, humpback snapper L. gibbus and bluestriped snapper L. kasmira) and the bluespotted grouper Cephalopholis argus. Between 1955 and 1961, 3200 small $(<25 \mathrm{~cm})$ L. kasmira were transported from the Society Islands (Moorea, 728 individuals) and the Marquesas Islands (Nuku Hiva, 2472 individuals) to Hawaii (O'ahu only) and 2204 small L. fulvus were transported from the Society Islands (2021 individuals), the Marquesas Islands (35 individuals), and the Canton Islands (Kiribati, 148 individuals) to Hawaii (O'ahu only). The distinct aspect of this case study compared with others is that the qualitative and quantitative protocol of introduction is known, whereas for most biological invasions, which are usually unintentional and undesired, such information is lacking.

Since their introduction to the Hawaiian Islands in the 1950s, introduced snappers belonging to the genera Lutjanus became extremely abundant (Friedlander et al. 2002, Schumacher \& Parrish 2005) and have become the focus of considerable attention in the sci- entific and recreational community because of their possible effect on local marine communities. It has been suggested that the introduced snappers may adversely affect native fish species through competition for spatial and/or dietary resources (Parrish et al. 2000, Schumacher \& Parrish 2005). For example, habitat use patterns of the native yellowtail goatfish Mulloidichthys vanicolensis (Family: Mullidae) are very similar to those of introduced $L$. kasmira and asymmetrical competition occurs for shelter (Schumacher \& Parrish 2005). In addition to the potential direct threat to native reef fish communities in terms of competition and predation, the introduction of nonindigenous fishes could also lead to the introduction of exotic parasites. The compositions of parasite communities are generally influenced by host ecology and phylogeny. Sympatric and phylogenetically related hosts with similar ecologies should have similar parasite communities (Muñoz et al. 2006). Therefore, transfer of parasites between native and introduced hosts usually concerns hosts that are closely related phylogenetically or ecologically. In the Hawaiian waters, parasite transfers may occur between introduced snappers and native Lutjanidae (phylogenetically related species) as well as native Mullidae (ecologically related species), such as the native syntopic M. vanicolensis. Despite the potential threat from the spread of exotic parasites, there is limited information on the parasites of introduced snappers in the Hawaiian Islands with the exception of protozoan (Work et al. 2003) and nematode parasites (Font \& Rigby 2000).

Before their release in the Hawaiian Islands, these snappers were bathed in copper sulphate (concentration of 0.4 to $0.8 \mathrm{ppm}$ ) to remove their parasites (Fujimura 1957-1958, Randall \& Kanayama 1982). In the 1950s, copper sulphate was assumed to be an effective anti-parasite treatment, but unfortunately, subsequent studies have shown that it is has a relatively poor ability to control infections. In addition, such treatment remains ineffective against internal parasites. Thus, it is suspected that parasites were released in the Hawaiian Islands with the massive introduction of 5404 lutjanids from Polynesia. Here, we compared the parasite communities of Lutjanus kasmira and L. fulvus in their native range (i.e. the Society and Marquesas islands) to the parasites on these fishes in $\mathrm{O}^{\prime} \mathrm{ahu}$, Hawaii, where these 2 snappers were introduced 50 yr ago. Then we investigated the potential introduction of parasites into the Hawaiian Archipelago and experimentally evaluated the effectiveness of copper sulphate as a means of removing parasites to explain possible parasite introduction. Finally, we investigated the possible transfer of introduced parasites to the abundant native syntopic Mulloidichthys vanicolensis. 


\section{MATERIALS AND METHODS}

Sites and host collection. A total of 446 fish were collected off the north coast of Moorea Island $\left(17^{\circ} 30^{\prime} \mathrm{S}\right.$, $149^{\circ} 50^{\prime} \mathrm{W}$, Society Archipelago, French Polynesia) in 2 sampling events: (1) in February to April 2006 (99 Lutjanus kasmira and 77 L. fulvus), and (2) in May to July 2007 (132 L. kasmira and 138 L. fulvus). Additionally, a total of 85 fish ( 72 L. kasmira and 13 L. fulvus) were collected from the Marquesas Islands $\left(8^{\circ} 57^{\prime} \mathrm{S}\right.$, $139^{\circ} 35^{\prime}$ W, near Ua Huka, French Polynesia) in March 2007. Fish were collected by means of a spear gun from both the inner and outer reefs at depths ranging from 5 to $40 \mathrm{~m}$. Immediately upon collection, each fish was individually enclosed within a Ziploc plastic bag. This prevented the loss of ectoparasites, particularly those that were not permanently attached (Grutter 1995). Plastic bags were stored on ice in a cooler until the fish were dissected (within 2 to $6 \mathrm{~h}$ ).

A total of 226 fish were collected from the Hawaiian Islands $\left(21^{\circ} 17^{\prime} \mathrm{N}, 157^{\circ} 53^{\prime} \mathrm{W}\right.$, south coast of $\left.\mathrm{O}^{\prime} \mathrm{ahu}\right)$ in 2 sampling events: (1) in April 2006 (66 Lutjanus kasmira and 32 L. fulvus), and (2) April and May 2007 (88 L. kasmira and 40 L. fulvus). Because of logistical constraints, we hired a local fisher to catch snappers by means of hook and line and fishing net from both the inner and outer reefs at depths ranging from 10 to $60 \mathrm{~m}$. As soon as fish were on the boat each fish was placed in an individual Ziploc plastic bag and stored on ice until dissection. All snappers sampled in Polynesia and Hawaii were sexually mature and their length measurements overlapped throughout all localities. Gills of an additional 153 native Mulloidichthys vanicolensis were also purchased at local fish markets in Honolulu in 2006 and 2007.

Parasite collection. Fish were examined for parasites under a dissecting microscope. Monogeneans were fixed on a slide with a drop of ammonium picrateglycerine (Malmberg 1957) or with a drop of Berlese fluid. Copepods and isopods were fixed in cold ethanol $(70 \%)$ and nematodes were fixed in hot ethanol (70\%). Leeches and cestodes were flattened alive on a slide by applying a cover slip and then fixed. Parasite species with prevalences greater than $50 \%$ are referred to as 'common species,' those with prevalences less than $10 \%$ are referred to as 'rare species' and those for which fewer than 5 individuals were found are referred to as 'incidental species.'

Experiments. For the copper sulfate exposure experiments, Lutjanus kasmira and L. fulvus were caught with hook and line off the north coast of Moorea Island. Fish were kept in 3001 saltwater aquaria. The water within all aquaria was aerated using low-flow air stones and filtered through a charcoal filter. Once each week, two-thirds of the water in each aquarium was replaced with unfiltered water from Oponuhu Bay in Moorea (salinity $32 \%$ ). The aquaria were maintained in a room at 23 to $28^{\circ} \mathrm{C}$ with natural light and water temperature similar to that from the ocean. Frozen mackerel was added twice daily to each aquarium until the fish stopped eating. Each fish species was kept in separate aquaria with a maximum of 13 fish per aquarium. All fish were kept for at least $30 \mathrm{~d}$ in aquaria before any experiment to allow the fish to acclimatise and to increase monogenean intensity. In all of the experiments described below, only the 6 most abundant monogenean species were counted: Diplectanum fusiforme, Euryhaliotrema chrysotaeniae, E. spirotubiforum, Haliotrema longitubocirrus, H. patellacirrus and $H$. sp. conf. anguiformis. Those species have been selected because of their likely introduction to the Hawaiian Archipelago (see 'Discussion') and their high abundance.

In vitro mortality: Ten Lutjanus fulvus and 10 L. kasmira were killed and the gills extracted. Gills were then placed in Petri dishes and covered with seawater. Monogeneans were removed from the gills with needles under a dissecting microscope. Each monogenean was immediately placed in an individual $1 \mathrm{ml}$ vial that was randomly filled with one of the following: seawater (control), copper sulphate $\left(0.4,0.8\right.$ or $\left.1.6 \mu \mathrm{g} \mathrm{l}^{-1}\right)$, formalin $\left(75 \mathrm{mg} \mathrm{l}^{-1}\right)$ or freshwater. The concentrations of copper sulphate used correspond to the minimum $\left(0.4 \mu \mathrm{g} \mathrm{l}^{-1}\right)$, maximum $\left(0.8 \mu \mathrm{g} \mathrm{l}^{-1}\right)$ and twice the maximum $\left(1.6 \mu \mathrm{g} \mathrm{l}^{-1}\right)$ concentrations used to treat fish before their introduction to the Hawaiian Islands $50 \mathrm{yr}$ ago (Randall 1960). Freshwater and formalin were not used in the late $1950 \mathrm{~s}$, but are used in the present study in a comparative manner.

Every hour all parasites were stimulated with a thin needle and their reaction was observed. Live monogeneans generally tie themselves into knots upon stimulation, whereas inactive monogeneans were assumed to be dead. Each individual that was assumed to be dead for $2 \mathrm{~h}$ was fixed on a slide and identified. The experiment continued until all parasites were dead. The experiment was replicated 4 times using 25 monogeneans of each parasite species from each host fish species (i.e. Lutjanus fulvus and L. kasmira) in each treatment. Thus, there were a total of 200 individuals of each monogenean species in each treatment for a total of 7200 individuals $(25$ individuals $\times 6$ species $\times 4$ replicates $\times 6$ treatments $\times 2$ hosts).

In vivo mortality: After $30 \mathrm{~d}$ in laboratory aquaria, 15 Lutjanus kasmira were transferred to a single aquarium with $0.8 \mathrm{ppm}$ copper sulphate solution. The control group of $10 \mathrm{~L}$. kasmira was maintained in single seawater aquarium for the same period. After $24 \mathrm{~h}$, all fish were killed and dissected. 
Cross-infection: Fifteen Mulloidichthys vanicolensis were caught with a hook and line in the lagoon off the north coast of Moorea on May 2007 in the same general location as were Lutjnaus kasmira described above. Fish were transferred to aquaria the day of capture (see description above for aquaria and feeding conditions) with 13 fish per aquarium. After allowing the $M$. vanicolensis to acclimatise to laboratory conditions for $30 \mathrm{~d}$, the fish were randomly assigned to one of three $300 \mathrm{l}$ aquaria and $5 \mathrm{M}$. vanicolensis, 4 L. kasmira and $4 \mathrm{~L}$. fulvus were placed in each aquarium. After $30 \mathrm{~d}$, all fish were killed and dissected. None of the fish in this experiment were used in any of the previous experiments.

Data analysis. Differences in prevalence were analyzed using Fisher's exact test. Intensity of each parasite species between 2006 and 2007 was compared with an analysis of covariance (ANCOVA) with fish standard length as a covariate. Data were $\log _{10}(x+1)$ transformed to satisfy the assumptions of the ANCOVA. Survival data were analyzed using a Cox regression (Cox 1972). Treatment, host species and replicate were included as factors in the survival analysis.

\section{RESULTS}

\section{Parasite diversity}

All Polynesian fish investigated were infected with a highly diverse parasite community: Acanthocephala, Annelida, Cestoda, Copepoda, Digenea, Isopoda, Monogenea and Nematoda (Table 1). As no significant differences were observed in Moorea between 2006 and 2007 for any parasite species or taxon (Fisher's exact test and ANCOVA, $\mathrm{p}>0.1$, respectively, for prevalence and mean intensity), the data in Table 1 are for both sampling years combined. However, prevalence and mean intensity for the fishes from Hawaii were significantly different between 2006 and 2007 (Fisher's exact test and ANCOVA, p < 0.01).

Although not all of the parasites were identified to species, we found more than 30 taxa belonging to 17 families in Polynesia. The Marquesas Islands and the Society Islands had different parasite communities. Although Lutjanus fulvus had 10 parasite species/taxa common to both locations, there was 1 unique species/taxon in the Marquesas Islands and 9 unique species/taxa in the Society Islands. However, several of these unique parasites were found with low prevalence and are not reliable data (see Table 1). Similarly, L. kasmira had 13 parasite species/taxa common to both locations, 9 unique species/taxa in the Marquesas Islands, and 4 unique species/taxa in the Society

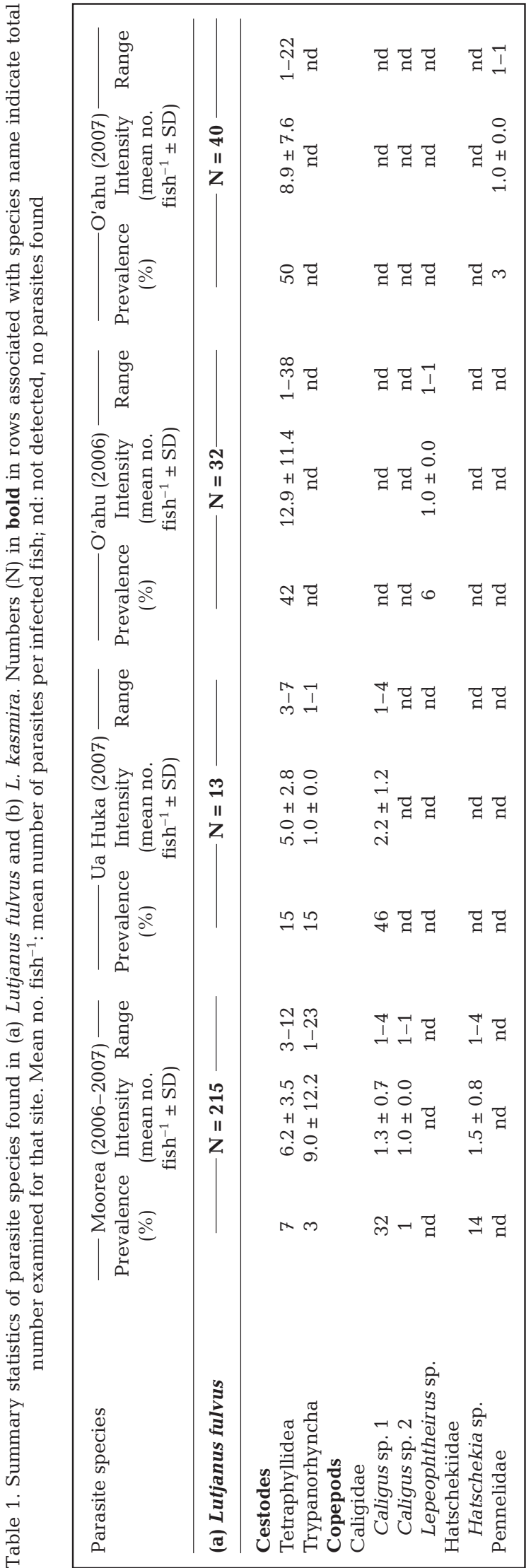




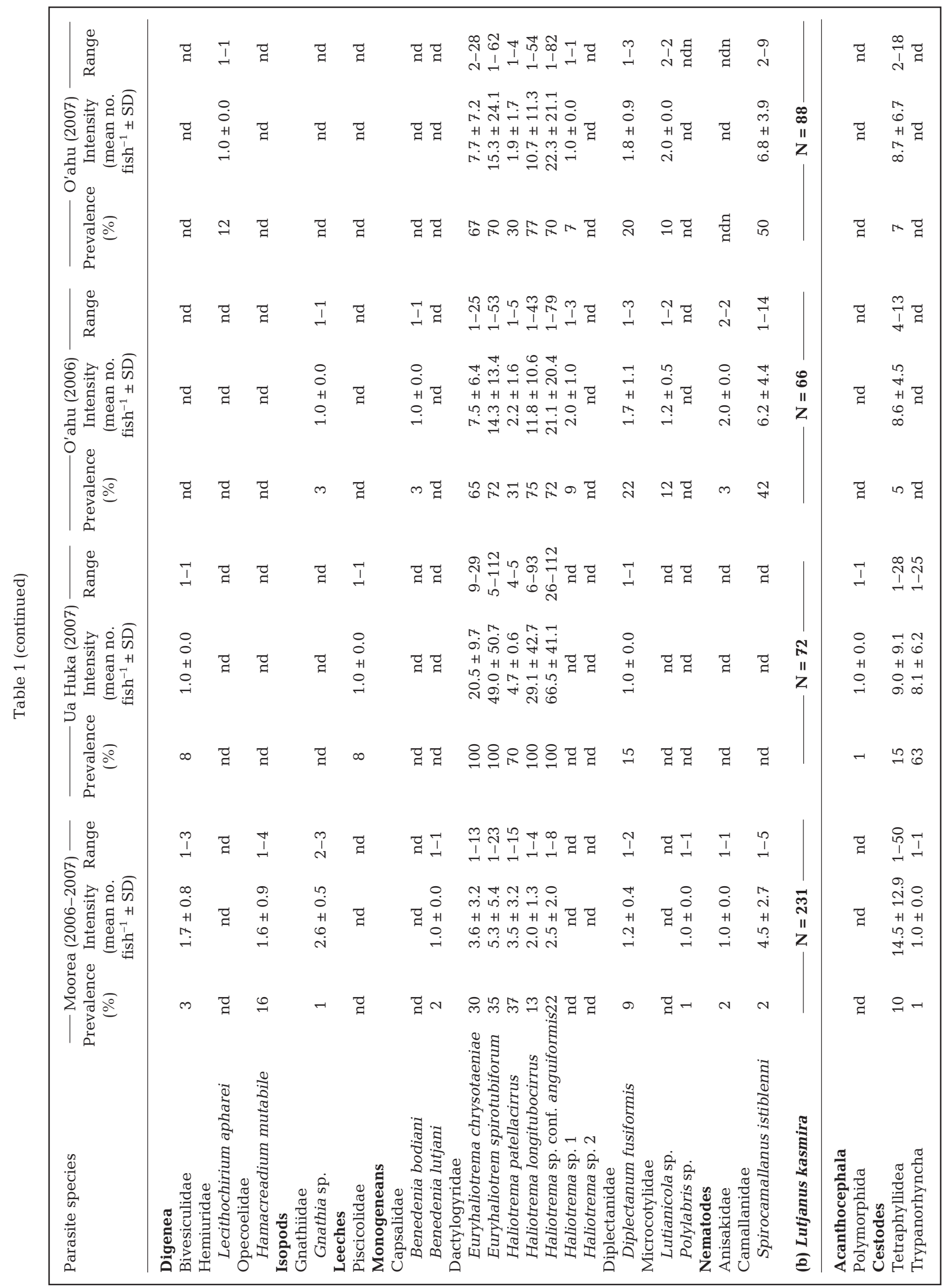




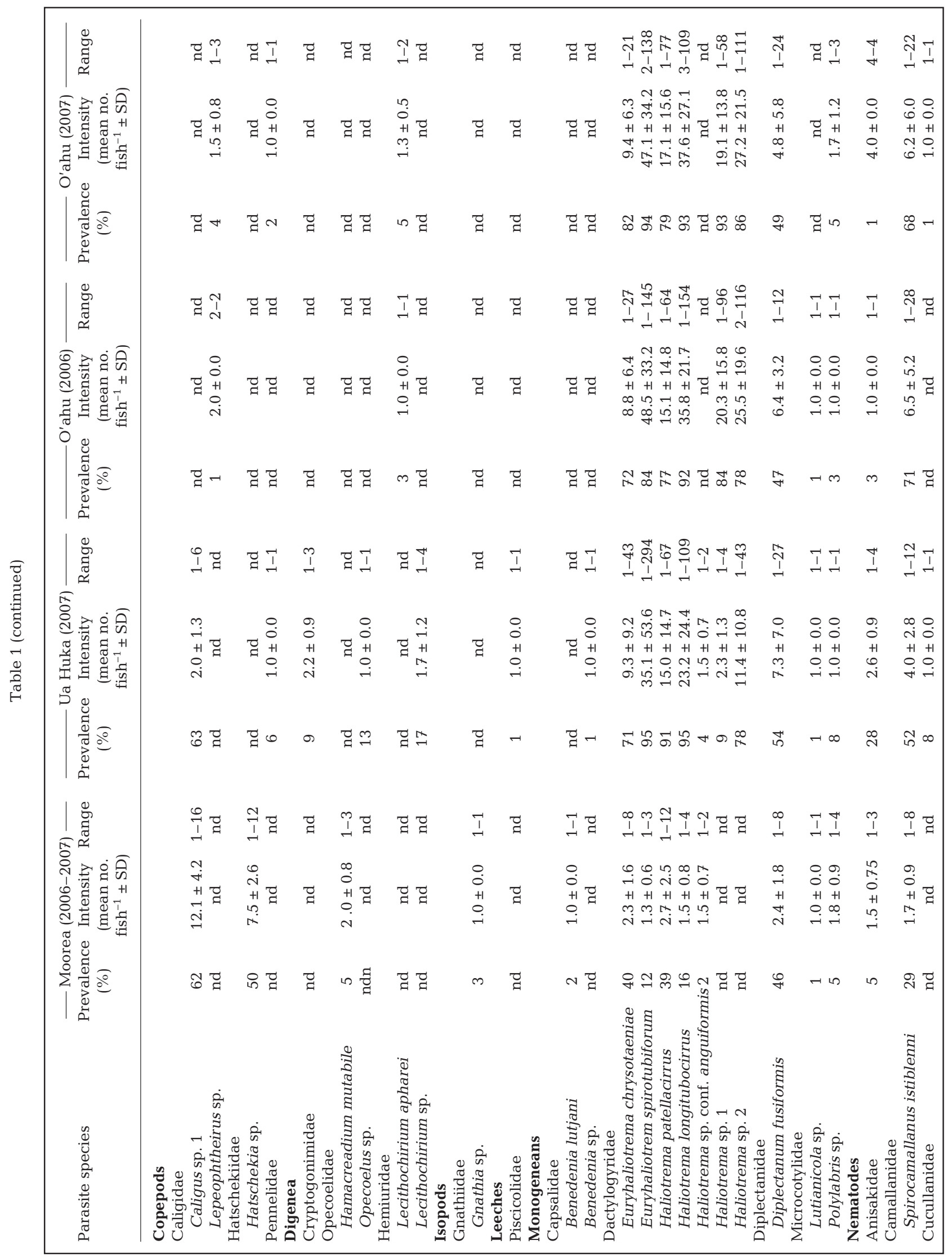


Islands. Monogeneans were the most diverse and abundant parasite group found in French Polynesia and belonged to 4 families. In the Society Islands, L. fulvus and L. kasmira were both infected by 9 monogenean species ( 5 common species, 1 rare species and 3 incidental species). All monogenean species (except the rare Benedenia lutjani) found in the Society Islands were also found in the Marquesas Islands, although 3 additional undescribed species were only found in the Marquesas Islands. Ancyrocephalid and diplectanid monogeneans found in both locations had higher intensities (up to 27 times higher) in the Marquesas Islands.

The parasite communities of fish from the Hawaiian Islands exhibited lower parasite species richness than in French Polynesia. Although some of the monogenean species found were common to both French Polynesia and the Hawaiian Islands, none of the copepod, isopod, leech and digenean species found in French Polynesia were found in the Hawaiian Islands. Despite this difference in the parasite communities, only 3 parasites that were identified to the species level were found exclusively in the Hawaiian Islands: Lepeophtheirus sp., Benedenia bodiani and Lecithochirium apharei. Although anisakids, gnathiids, pennelids, tetraphillideans (all larvae stages) and cucullanids were found in fishes from both French Polynesia and the Hawaiian Islands (Table 1), these taxa were only identified to family, making the introduction of species from these families undetectable in this study. Nonetheless, 10 monogenean species and the nematode Spirocamallanus istiblenni were found in both the Hawaiian Islands and French Polynesia.

Mulloidichthys vanicolensis from Hawaii had a mean $( \pm \mathrm{SD})$ of $85.3 \pm 30.2$ monogeneans per host. Due to the method used to collect these fish (i.e. fish were purchased at local fish markets and were not individually bagged upon capture), quantitative assessment may be biased low. However, among the more than 13000 monogenean individuals observed, none corresponded to species found on the 2 introduced snappers. All monogeneans belonged to the family Ancyrocephalidae and were already described by Yamaguti (1968). They were all morphologically distinct from those on M. vanicolensis in Moorea.

\section{Experiments}

\section{In vitro mortality}

When comparing the copper sulphate treatments of 0.4 and 0.8 ppm to the control (seawater), there was no significant effect of replicate or host species but there was a significant effect of treatment (Table 2). The mortality of 5 ancyrocephalids and 1 diplectanid by treatment is shown in Fig. 1. Although there was a significant effect of copper sulphate on parasite mortality (Table 2), the difference in survival between control (seawater) and copper sulphate at either 0.4 or $0.8 \mathrm{ppm}$ was relatively minor, as shown in Fig. 1. Copper sulphate at $1.6 \mathrm{ppm}$ (double of the maximum concentration used $50 \mathrm{yr}$ ago) cause noticeably higher mortality than at either 0.4 or $0.8 \mathrm{ppm}$, but was still very low even after several hours. In contrast, formalin and freshwater treatments caused much higher parasite mortalities, as $90 \%$ of the monogeneans died after only $2 \mathrm{~h}$ (compared with less that $10 \%$ after $2 \mathrm{~h}$ for copper sulphate at $1.6 \mathrm{ppm}$ ).

\section{In vivo mortality}

No significant differences were found in mean parasite intensity between treatments with and without copper sulfate for both the total number of monogeneans and each monogenean species (Mann-Whitney $U$-test, $\mathrm{p}>0.5$ ). For each treatment, all monogeneans species remained on their host with a prevalence of $100 \%$ and, thus, monogenans diversity was equal between treated and untreated fish. While the experimental design consisted of pseudo-replicated data (replicates should consist of several aquaria with or without treatment, not fishes within 2 separately treated aquaria), it nevertheless provided reliable in vivo evidence that copper sulphate is ineffective at removing monogeneans.

\section{Cross-infection}

While monogenean intensities on Lutjanus kasmira and L. fulvus increased by more than 15 times (compared with typical intensity in the field) over the $30 \mathrm{~d}$ that the fish were maintained in aquaria, none of the monogenean species found on either L. kasmira or L. fulvus were found on Mulloidichth vanicolensis at the end of the experiment.

Table 2. Results of Cox regression testing for differences in the mortality of 6 monogenean species (see Fig. 1) by treatment (seawater, copper sulphate 0.4 and $0.8 \mathrm{ppm}$ ), host species (Lutjanus fulvus and L. kasmira), and replicate (4 replicates)

\begin{tabular}{|lcccccc|}
\hline & Beta & SE & t-value & $\begin{array}{c}\text { Exponent } \\
\text { beta }\end{array}$ & $\begin{array}{c}\text { Wald } \\
\text { statistics }\end{array}$ & p-value \\
\hline Treatment & 0.292 & 0.051 & 5.682 & 1.340 & 32.285 & $<0.0001$ \\
Host species & 0.027 & 0.033 & 0.800 & 1.027 & 0.640 & 0.42 \\
Replicate & 0.013 & 0.015 & 0.844 & 1.013 & 0.712 & 0.39 \\
\hline
\end{tabular}



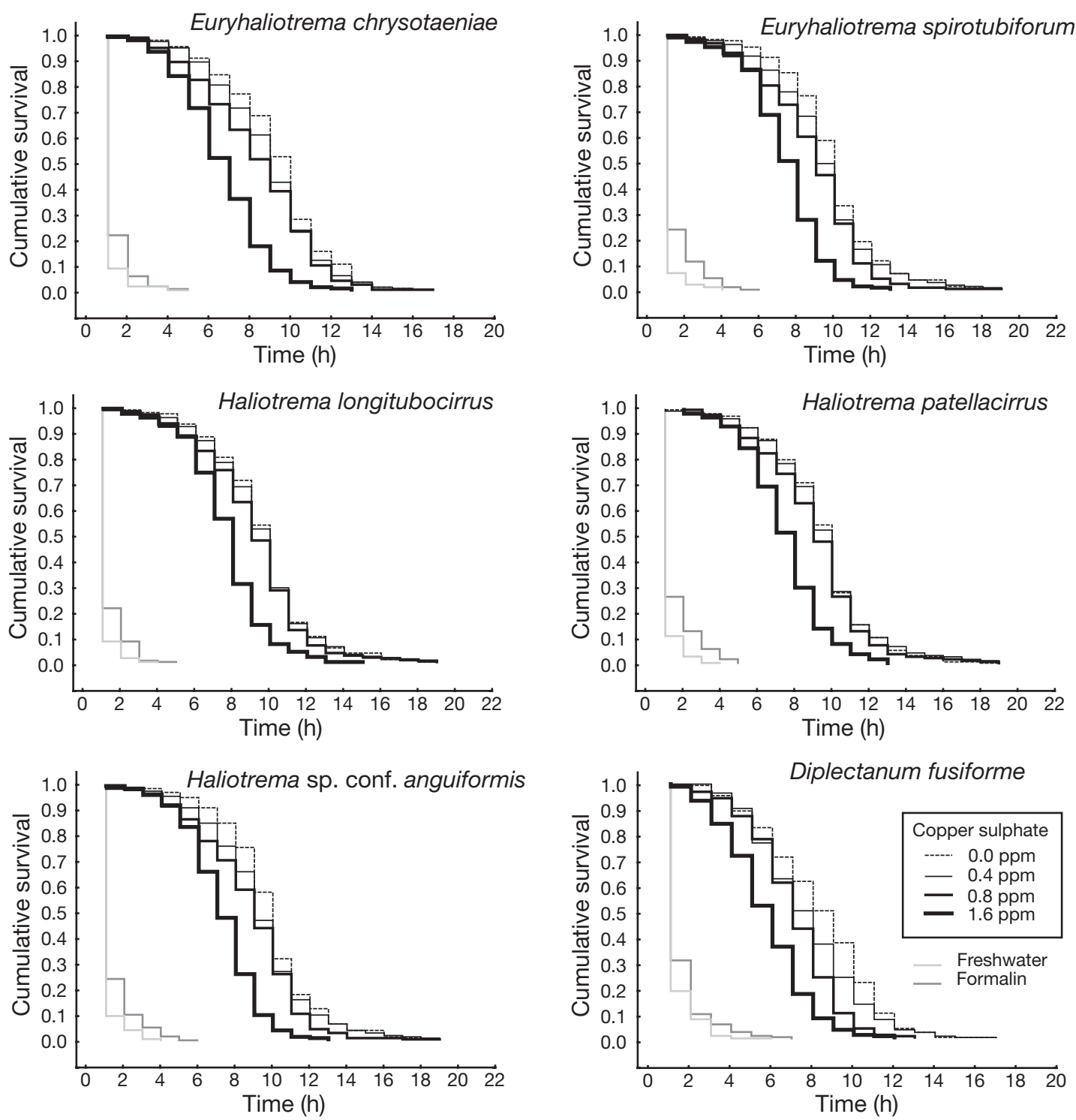

Fig. 1. Cumulative survival curves of 6 monogenean species (5 ancyrocephalids and 1 diplectanid) found in Lutjanus fulvus and L. kasmira. Six treatments were tested in vitro: seawater without copper sulphate and with copper sulphate $(0.4,0.8$ and 1.6 ppm), freshwater and formalin $\left(75 \mathrm{mg} \mathrm{l}^{-1}\right)$. A total of 200 parasites were analyzed for each curve (4 equal replicates together)

\section{DISCUSSION}

We initially suspected that parasites were released in the Hawaiian Islands with the massive introduction of 5404 lutjanids from Polynesia. The comparison of the whole parasite communities associated with Lutjanus kasmira and L. fulvus between their native range and their introduced range suggests that (1) most natural parasites were lost, (2) local transfer of parasites from native to introduced fish were scarce, and (3) several parasites were introduced to the Hawaiian Archipelago. Moreover, experimental data confirmed the ineffectiveness of copper sulphate at a concentration of
0.4 to $0.8 \mathrm{ppm}$ as a means of removing parasites, and instead favoured parasite introduction. Finally, a crossinfection experiment and parasitological data supported the hypothesis that the transfer of introduced parasites to the native syntopic Mulloidichthys vanicolensis did not occur.

\section{Parasites lost}

In the Hawaiian Islands, fish had less diverse parasite communities than in French Polynesia. None of the copepods, isopods, leeches and digeneans found in 
Lutjanus kasmira and L. fulvus in French Polynesia were introduced with their hosts to the Hawaiian Islands. This loss of parasite species may be due to several factors, including the following: (1) the antiparasite treatment was applied before introduction (experiments only referred to monogeneans and almost nothing is known about the effectiveness of copper sulfate at 0.4 to $0.8 \mathrm{ppm}$ on other taxa), (2) the lack of appropriate intermediate host species for parasites with complex life cycles, (3) vulnerability to local environmental conditions and predators (e.g. cleaner fish and shrimp) and (4) the inability to maintain a viable population in a low host-density or parasitedensity population (see Torchin et al. 2002 for a general discussion).

\section{Parasite transfer from native to introduced fish}

The 3 parasite species that were only found on Lutjanus kasmira and L. fulvus in the Hawaiian Islands (i.e. Benedenia bodiani, Lecithochirium apharei and Lepeophtheirus sp., Table 1) are assumed to be the result of parasite transfer from native to introduced hosts. Adult Lepeophtheirus sp. as well as caligid and penellid larvae generally have low host specificities (Boxshall 1998). Anisakid and tetraphillidean larvae (which are trophically transmitted) also have low host specificities and may parasitize introduced snappers as paratenic or intermediate hosts. B. bodiani is the only native (i.e. species found only in the Hawaiian Islands) capsalid species found on the gills of the introduced snappers in the Hawaiian Islands. Because this species was originally described on the gills of Bodianus bilunulatus (Labridae) in the Hawaiian Islands and because only a single individual was found, we suggest that it more probably resulted from a transfer of the parasite occurring in a crowded fishing net. Interestingly, L. apharei has previously been reported in Aphareus furca (Lutjanidae) in the Hawaiian Islands (Yamaguti 1970); these fish live in shallower waters than do other deep-bottom snappers (Parrish et al. 2000). Since L. apharei is acquired by its fish hosts through the food that they consume, its presence in L. fulvus and L. kasmira suggests that these 2 fishes feed (at least occasionally) on the same prey items as A. furca, whose diet is unknown at present.

Parasite species that were only found in the Hawaiian Islands had low prevalences $(<6 \%)$ and intensities $\left(<3 \mathrm{fish}^{-1}\right)$ in Lutjanus kasmira and L. fulvus (Table 1). Although introduced hosts were naïve to local parasites, our data suggest that the native parasites have been relatively incapable of infecting the introduced fish species. Thus, the lack of native parasites may have contributed to the successful introduction and rapid spread of L. fulvus and L. kasmira in the Hawaiian Islands. It is frequently argued that species are more likely to become invasive when they are released from the pressure of their enemies (i.e. competitors and parasites) in their new territories, as stated by the Enemy Release Hypothesis (Mitchell \& Power 2003, Torchin et al. 2003). When introduced organisms are susceptible to native parasites, pressure from their own natural parasite species is generally less important than that from the related indigenous parasite species because hosts may have limited specific defences towards the latter.

\section{Introduction mechanisms}

Before their introduction to the Hawaiian Islands in the 1950s, numerous fish were kept in small circular pens in French Polynesia for several weeks (Randall 1960) until they were shipped almost $4500 \mathrm{~km}$ on a research vessel. This high density stocking in pens and onboard the boat may have favoured the rapid increase in population density of parasites with a direct life cycle, such as monogeneans (Leong \& Wong 1988, Scholz 1999, Johnson et al. 2004, Bondad-Reantaso et al. 2005). After transportation and before their release, potentially heavily infected fish were treated for 19 to $24 \mathrm{~h}$ with copper sulphate at a concentration of 0.4 to $0.8 \mathrm{ppm}$ to remove external parasites (Fujimura 1957-1958). Copper sulphate was assumed to be an effective anti-parasite treatment, but unfortunately, subsequent studies have shown that it has a relatively poor ability to control monogenean infections, especially because of their resistant eggs (Thoney 1990, Liang \& Leong 1992, Ogawa 1996).

Our experimental results show that copper sulphate was relatively ineffective at killing monogenans (both ancyrocephalids and diplectanids) that had been removed from their hosts. Although higher concentrations than those used $50 \mathrm{yr}$ ago to treat fish are more effective (e.g. 1.6 ppm resulted in higher mortality in monogeneans separated from their hosts than did 0.4 or 0.8 ppm, Fig. 1), the use of copper sulphate at concentrations known to be effective at killing monogeneans and other parasites is prohibited by the US Food and Drug Administration as these concentrations are also toxic to fish. Copper sulphate is currently used as an algicide only (Hawkins \& Griffiths 1987). In contrast, formalin and/or freshwater are much more effective at killing marine monogeneans (Fig. 1) (Fajer-Ávila et al. 2007). If either freshwater or formalin had been used to treat the fish before their release in the Hawaiian Islands, the probability of introducing exotic parasites would have been much reduced. Thus, it is likely that a large number 
of parasites (both adults and eggs) were released in the Hawaiian Islands along with their hosts in the 1950s.

Generally, intensity and prevalence increase with host population density (Arneberg et al. 1998). On the other hand, there is also a lower host density threshold below which parasite populations are not able to persist (Lafferty \& Kuris 1999, Torchin et al. 2002). After the fish were released in the Hawaiian Islands, host densities were probably relatively low and the host population size was also small. Therefore, any parasite species that were introduced along with their fish hosts may have been vulnerable to the effects of a small host population size; i.e. local extinction for the introduced parasite species could occur. However, fish were introduced to the Hawaiian Islands in large numbers (e.g. 2447 Lutjanus kasmira in June 1958), and individuals tended to remain in the area in which they were introduced (Fujimura 1957-1958, Randall 1960). Further, the L. kasmira population in the Hawaiian Islands has dramatically increased since its introduction (Oda \& Parrish 1981, Randall \& Kanayama 1982, Randall et al. 1993b). Such host behaviour and demographic expansion may have favoured the establishment of the exotic monogenean species that were introduced to the Hawaiian Islands with their fish hosts. Moreover, the copper sulphate treatment only affected external parasites, and internal parasites (e.g. the nematode Spirocamallanus istiblenni) might have been successfully transported from French Polynesia to the Hawaiian Islands.

\section{Parasite introduction}

Our results showed that several monogeneans occurred both in the native and the introduced range of their hosts. However, we are not able to determine whether these parasites were introduced with their fish hosts to the Hawaiian Islands or whether the parasites were already in the Hawaiian Islands at the time the fish were introduced. In the following discussion, we present our hypotheses for several different parasite groups.

\section{Ancyrocephalidae and Diplectanidae}

The monogeneans of native reef and shore fishes from the Hawaiian Islands have been relatively well studied, and among the 55 Ancyrocephalinae and the 11 Diplectanidae identified by Yamaguti (1968) none are similar to those found on the introduced species. Observed ancyrocephalids and diplectanids belonging to genera Euryhaliotrema, Haliotrema and Diplec- tanum have only been reported from lutjanids belonging to the genus Lutjanus. No Lutjanus spp. naturally occur in the Hawaiian Islands, and lutjanids belonging to the genera Aphareus, Aprion, Etelis and Pristipomoides that inhabit deeper water in the Hawaiian Islands have a different parasitofauna that does not include any ancyrocephalids (Yamaguti 1968). Therefore, we suggest that E. chrysotaeniae, E. spirotubiforum, $H$. longitubocirrus, $H$. patellacirrus, $H$. conf. anguiformis and $D$. fusiforme are not native to the Hawaiian Islands. We also suggest that the 2 undescribed ancyrocephalids (Haliotrema sp. 1 and sp. 2), which have most of the morphological features that characterise ancyrocephalids from snappers of the genus Lutjanus from the China Sea and the Gulf of Mexico (Bychowsky \& Nagibina 1971, Zhukov 1976, Kritsky \& Boeger 2002), are also non-indigenous in the Hawaiian Islands and have been introduced with Marquesan hosts.

\section{Microcotylidae}

The 2 undescribed Microcotylidae found in both French Polynesia and the Hawaiian Islands are morphologically identical, including the fine morphological features of the genitalia and clamps. Given the high degree of host specificity of most microcotylid monogeneans (see Hayward 1996, Yang et al. 2007 for the genus Polylabris) and the identical morphologies of both species in French Polynesia and the Hawaiian Islands, it is more likely that these 2 species are non-indigenous in the Hawaiian Islands and have been introduced from French Polynesia. However, in the absence of a formal identification, and because only a few individuals were observed throughout all localities, these 2 monogeneans should be referred to as cryptogenic species sensu Carlton (1996) (i.e. 'a species that is not demonstrably native or introduced').

\section{Spirocamallanus istiblenni}

The nematode Spirocamallanus istiblenni also needs special consideration. This species was originally described in the Hawaiian Islands (Noble 1966), but occurs in most parts of the Pacific Ocean (Rigby \& Font 1997). S. istiblenni has been reported in 18 carnivorous fish species of 11 families from 2 orders (Hasegawa et al. 1991, Rigby \& Font 1997). Despite its uncertain status in the Hawaiian Islands (i.e. native or introduced) (Font \& Rigby 2000), this nematode currently occurs both in French Polynesia and the Hawaiian Islands and parasitises several native fish species, 
including Mullidae (Mulloidichthys spp. and Parupeneus spp.) in the Hawaiian Islands. However, it is not clear whether this species is native to the Hawaiian Islands, is introduced, or may be represented by both native and introduced populations (that may or may not hybridise). Thus, $S$. istiblenni should still be referred to as cryptogenic and further molecular work on this species should be done to provide a more precise answer. Alternately, it may be possible to determine whether this parasite was introduced by examining specimens of native Hawaiian fishes deposited in natural history museums before the Polynesian snapper introduction.

Further, we suggest that 8 monogenean species have been introduced with Lutjanus kasmira and L. fulvus to the Hawaiian Islands from French Polynesia and this nematode as well as 2 additional monogeneans should be referred as to cryptogenic.

\section{Threat to native communities}

Coral reef fish generally become parasitised after recruitment (Rigby \& Dufour 1996, Cribb et al. 2000) via the ingestion of prey items that were not consumed during the larval stage or through congeneric contacts, or both. The parasite community of fish species is generally influenced by host ecology and phylogeny. Therefore, sympatric and closely related host species with similar ecologies should have similar parasite communities (Muñoz et al. 2006, 2007). In the Hawaiian Islands, since there are no native snappers of the genus Lutjanus, transmission from the introduced species to native other lutjanids (i.e. deep-water snappers) or species with similar ecological relationships are more likely. Therefore, there is some concern that diseases and/or parasites from L. kasmira and L. fulvus may threaten the existing valuable commercial and recreational handline deep-water snapper (Parrish et al. 2000) and goatfish fisheries. Further, some goatfishes are 'species of greatest conservation need' (Mitchell et al. 2005).

As previously stated, deep-water snappers of the genera Aphareus, Aprion, Etelis and Pristipomoides occur in Hawaiian waters. Parrish et al. (2000) stated that Lutjanus kasmira is exclusively present at depths significantly shallower than all of the native snappers, except Pristipomoides filamentosus, but L. kasmira feed near the bottom whereas $P$. filamentosus feed considerably higher up in the water column. Thus, parasite transfer from the introduced snappers to native deep-water lutjanids is highly unlikely, at least for ectoparasites whose mobility is largely determined by their hosts. Moreover, deep-water snappers have a markedly different parasitofauna, excluding ancyrocephalids, from the snappers found in shallower waters (Yamaguti 1968). In general, the monogeneans species found on deep-sea fishes are largely unrelated to those found on surface-water fishes in the same geographical area (Rohde 1988, 2002). Even though native Hawaiian snappers are not syntopic with introduced snappers and parasite transfer is highly unlikely, we recognize that parasitological data remain to be collected to confirm the absence of such transfer.

Parupeneus multifasciatus, Mulloidichthys flavolineatus and $M$. vanicolensis are the most common species of goatfish (Mullidae) on O'ahu. The habitat use patterns of $M$. vanicolensis are very similar to those of Lutjanus kasmira (Schumacher \& Parrish 2005). In French Polynesia, where species belonging to these 3 genera (i.e. Lutjanus, Mulloidichthys and Parupeneus) naturally occur, Mulloidichthys and Parupeneus do not have any parasite species in common with Lutjanus spp. In the Hawaiian Islands, although these species are all infected with ancyrocephalids belonging to the genus Haliotrema (Yamaguti 1968), they have distinct monogenean communities. Ultimately, the introduced diplectanids and ancyrocephalids found on the gills of Lutjanus spp. in the Hawaiian Islands appear to be strongly genus-specific, or even speciesspecific, which fits with the high degree of host specificity that has been observed for monogeneans in general (Sasal et al. 1999, Whittington et al. 2000).

Fortunately, the native snappers and goatfish are both ecologically and phylogenetically distant from the 2 introduced snappers (Allen 1985, Parrish et al. 2000, Schumacher \& Parrish 2005). However, some degree of parasite transfer is still possible; e.g. the long-term evolution of the introduced monogeneans may ultimately allow parasite transfer.

Once a pathogen/disease agent or a parasite is introduced and becomes established in the natural environment, there is little or no possibility for eradication of either. Because the introduction of non-native marine organisms is one form of anthropogenic change that can cause irreversible alterations in marine communities, effective management strategies urgently need to be established (Perrings et al. 2005, Schlaepfer et al. 2005, Godwin et al. 2006). These strategies also need to consider the parasites of the introduced non-native marine organisms. Through education and effective management strategies, which include drastic preventive measures (e.g. quarantine, appropriate treatment; Cunningham 1996), the threat of marine invasions can be reduced.

Acknowledgements. We thank A. Kuris and R. Hechinger from the University of California Santa Barbara for revising this manuscript as well as anonymous reviewers who made valuable suggestions to improve the manuscript. 


\section{LITERATURE CITED}

Allen GR (1985) FAO species catalogue, Vol 6. Snappers of the world. An annotated and illustrated catalogue of lutjanid species known to date. FAO Fish Synop No. 125, Rome

> Anderson RM, May RM (1986) The invasion, persistence and spread of infectious diseases with animal and plant communities. Philos Trans R Soc Lond B Biol Sci 314:533-570

Arneberg P, Skorping A, Grenfell B, Read AF (1998) Host densities as determinants of abundance in parasites communities. Proc R Soc Lond B Biol Sci 265:1283-1289

Bax N, Williamson A, Aguero M, Gonzalez E, Geeves W (2003) Marine invasives alien species: a threat to global biodiversity. Mar Policy 27:313-323

Bondad-Reantaso MG, Subasinghe RP, Arthur JR, Ogawa K, Chinabut S, Adlard R, Tan Z, Shariff M (2005) Disease and health management in Asian aquaculture. Vet Parasitol 132:249-272

Boxshall GA (1998) Host specificity in copepod parasites of deep-sea fishes. J Mar Syst 15:215-223

Bychowsky BE, Nagibina LF (1971) New and little known species of the genus Haliotrema Johnston et Tiegs, 1922 (Monogenoidea). 2. Zool Zh 50:25-40

> Carlton JT (1996) Biological invasions and cryptogenic species. Ecology 77:1653-1655

> Coleman FC, Koenig CC, Huntsman GR, Musick JA and others (2000) Long-lived reef fishes: the grouper-snapper complex. Fisheries 25(3):14-21

Cox DR (1972) Regression models and life-tables. J R Stat Soc Ser B 34:187-220

> Cribb TH, Pichelin S, Dufour V, Bray RA and others (2000) Parasites of recruiting coral reef fish larvae in New Caledonia. Int J Parasitol 30:1445-1451

Cunningham AA (1996) Disease risks of wildlife translocations. Conserv Biol 10:349-353

> Dobson A, Foufopoulos J (2001) Emerging infectious pathogens of wildlife. Philos Trans R Soc Lond B Biol Sci 356: 1001-1012

Dogiel VA, Lutta A (1937) Mortality among spiny sturgeon of the Aral Sea in 1936. Rybn Khoz 12:26-27

Fajer-Ávila EJ, Velásquez-Medina SP, Betancourt-Lozano M (2007) Effectiveness of treatments against eggs, and adults of Haliotrema sp. and Euryhaliotrema sp. (Monogenea: Ancyrocephalinae) infecting red snapper, Lutjanus guttatus. Aquaculture 264:66-72

Font WF, Rigby M (2000) Implications of a new Hawaiian host record from blue-lined snappers Lutjanus kasmira: Is the nematode Spirocamallanus istiblenni native or introduced? Bishop Mus Occas Pap 64:53-56

Friedlander AM, Parrish JD, DeFelice RC (2002) Ecology of the introduced snapper Lutjanus kasmira (Forsskal) in the reef fish assemblage of a Hawaiian bay. J Fish Biol 60:28-48

Fujimura T (1957-1958) Introduction of marine game fishes from areas in the Pacific. Project No. F-5-R, Job No. 9. Reef and Inshore Game Fish Management Research, Territory of Hawaii, Honolulu, HI

Godwin S, Rodgers KS, Jokiel PL (2006) Reducing potential impact of invasive marine species in the Northwestern Hawaiian Islands Marine National Monument. Northwest Hawaiian Islands Marine National Monument Administration, Honolulu, HI

> Grosholz E (2002) Ecological and evolutionary consequences of coastal invasions Trends Ecol Evol 17:22-27

Grutter AS (1995) Comparison of methods for sampling ectoparasites from coral reef fishes. Mar Freshw Res 46: 897-903
Harvell CD, Kim K, Burkholder JM, Colwell RR and others (1999) Emerging marine diseases-climate links and anthropogenic factors. Science 285:1505-1510

Hasegawa H, Williams EHJ, Bunkley-Williams L (1991) Nematode parasites from marine fishes of Okinawa, Japan. J Helminthol Soc Wash 58:186-197

Hawkins PR, Griffiths DJ (1987) Copper as an algicide in a tropical reservoir. Water Res 21:475-480

Hay ME, Parker JD, Burkepile DE, Caudill CC, Wilson AE, Hallinan ZP, Chequer AD (2004) Mutualisms and aquatic community structure: the enemy of my enemy is my friend. Annu Rev Ecol Syst 35:175-197

$>$ Hayward CJ (1996) Revision of the monogenean genus Polylabris (Microcotylidae). Invertebr Taxon 10: 995-1039

Horwitz P, Wilcox BA (2005) Parasites, ecosystems and sustainability: an ecological and complex systems perspective. Int J Parasitol 35:725-732

Hudson PJ, Dobson AP, Lafferty KD (2006) Is a healthy ecosystem one that is rich in parasites? Trends Ecol Evol 21:381-385

Johnson SE, Treasurer JW, Bravo S, Nagasawa K, Kabata Z (2004). A review of impact of parasitic copepods on marine aquaculture. Zool Stud 43:229-243

Kritsky DC, Boeger WA (2002). Neotropical Monogenoidea. 41. New and previously described species of Dactylogyridae (Platyhelminthes) from the gills of marine and freshwater perciform fishes (Teleostei) with proposal of a new genus and hypothesis on phylogeny. Zoosystema 24: $7-40$

Lafferty KD, Kuris AM (1999) How environmental stress affects the impacts of parasites. Limnol Oceanogr 44: 925-931

> Leong TS, Wong SY (1988) A comparative study of the parasite fauna of wild and cultured grouper (Epinephelus malabaricus Bloch et Schneider) in Malaysia. Aquaculture 68:203-207

Liang KS, Leong TS (1992) Treatment of cultured golden snapper, Lutjanus johni Bloch, infected with monogeneans. Aquaculture 106:1-8

> Luque JL, Poulin R (2007) Metazoan parasite species richness in Neotropical fishes: hotspots and the geography of biodiversity. Parasitology 134:865-878

Malmberg G (1957) Om Förekomsten av Gyrodactylus på svenska fiskar. Skr Söd Sver Fiskför Årsskr 1956:19-76 (in Swedish)

McNeely JA (2001) Invasive species: a costly catastrophe for native biodiversity. Land Use Water Resour Res 1:1-10

Mitchell CE, Power AG (2003) Release of invasive plants from fungal and viral pathogens. Nature 421:625-627

Mitchell C, Ogura C, Meadows D, Kane A, Stromnier L, Fretz S, Leonard D, McClung A (2005) Hawai'i comprehensive wildlife conservation strategy. Hawaii's Comprehensive Wildlife Conservation Strategy, Honolulu, HI

> Muñoz G, Grutter AS, Cribb TH (2006) Endoparasite communities of five fish species (Labridae: Cheilininae) from Lizard Island: How important is the ecology and phylogeny of the hosts? Parasitology 132:363-374

Muñoz G, Grutter AS, Cribb TH (2007) Structure of the parasite communities of a coral reef fish assemblage (Labridae): testing ecological and phylogenetic host factors. J Parasitol 93:17-30

Murphy GI (1960) Introduction of the Marquesan sardine, Harengula vittata (Cuvier and Valenciennes), to Hawaii waters. Pac Sci 14:185-187

Noble ER (1966) A new camallanid nematode from Hawaii. Pac Sci 20:360-366 
Oda DK, Parrish JD (1981) Ecology of commercial snappers and groupers introduced to Hawaiian reefs. Proc 4th Int Coral Reef Symp, Manila, p 59-67

Ogawa K (1996) Marine parasitology with special reference to Japanese fisheries and marculture. Vet Parasitol 64: 95-105

Parrish JD, Aeby GS, Conklin EJ, Ivey GL (2000) Interactions of nonindigenous blueline snapper (Taape) with native fishery species. Final Report. US Geological Survey, Hawaii Cooperative Fishery Research Unit, Honolulu, HI

Perrings C, Dehnen-Schmutz K, Touza J, Williamson M (2005) How to manage biological invasions under globalization. Trends Ecol Evol 20:212-215

Pimentel D, Zuniga R, Morrison D (2005) Update on the environmental and economic costs associated with alieninvasive species in the United States. Ecol Econ 52: 273-288

Prenter J, Calum MN, Dick JTA, Dunn AM (2004) Roles of parasites in animal invasions. Trends Ecol Evol 19: 385-390

Randall JE (1960) New fishes for Hawaii. Sea Front 6:33-43

Randall JE (1987) Introductions of marine fishes to the Hawaiian Islands. Bull Mar Sci 41:490-502

Randall JE, Kanayama RK (1982) Hawaiian fish immigrants. Sea Front 18:144-153

Randall JE, Earle JL, Hayes T, Pittma C, Severns M, Smith RJF (1993a) Eleven new records and validations of shore fishes from the Hawaiian Islands. Pac Sci 47:222-239

Randall JE, Earle JL, Pyle RL, Parrish JD, Hayes T (1993b) Annotated checklist of the fishes of Midway Atoll, Northwestern Hawaiian Islands. Pac Sci 47:356-400

Rigby MC, Dufour V (1996) Parasites of coral reef fish recruits, Epinephelus merra (Serranidae), in French Polynesia. J Parasitol 82:405-408

Rigby MC, Font WF (1997) Redescription and range extension of Spirocamallanus istiblenni Noble, 1966 (Nematoda: Camallanidae) from coral reef fishes in the Pacific. J Helminthol Soc Wash 64:227-233

Rohde K (1988) Gill Monogenea of deepwater and surface fish in southeastern Australia. Hydrobiologia 160:271-283

Rohde K (2002) Ecology and biogeography of marine parasites. Adv Mar Biol 43:1-83

Ruiz GM, Fofonoff PW, Carlton JT, Wonham MJ, Hines AH (2000) Invasion of coastal marine communities in North America: apparent patterns, processes, and biases. Annu Rev Ecol Syst 31:481-531

Editorial responsibility: David Marcogliese, Montreal, Québec, Canada
Sasal P, Trouvé S, Müller-Graf C, Morand S (1999) Specificity and host predictability: a comparative analysis among monogenean parasites of fish. J Anim Ecol 68:437-444

Schlaepfer MA, Sherman PW, Blossey B, Runge MC (2005) Introduced species as evolutionary traps. Ecol Lett 8: 241-246

$>$ Scholz T (1999) Parasites in cultured and feral fishes. Vet Parasitol 84:317-335

Schumacher BD, Parrish JD (2005) Spatial relationships between an introduced snapper and native goatfishes on Hawaii reefs. Biol Invasions 7:925-933

> Thomas F, Poulin R, De Meeüs R, Guégan JF, Renaud F (1999) Parasites and ecosystem engineering: What roles could they play? Oikos 84:167-171

Thoney DA (1990) The effect of trichlorfon, praziquantel and copper sulfate on various stages of the monogenean Benedeniella posterocolpa, a skin parasite of the cownose ray, Rhinoptera bonasus (Mitchill). J Fish Dis 13:385-389

Torchin ME, Lafferty KD, Kuris AM (2002) Parasites and marine invasions. Parasitology 124:137-151

> Torchin ME, Lafferty KD, Dobson AP, McKenzie VJ, Kuris AM (2003) Introduced species and their missing parasites. Nature 421:628-630

- Whittington ID, Cribb TH, Hamwood TE, Hallday JA (2000) Host-specificity of monogenean (platyhelminth) parasites: a role for anterior adhesive areas. Int $\mathrm{J}$ Parasitol 30: 305-320

Work TM, Rameyer RA, Takata G, Kent ML (2003) Protozoal and epitheliocystis-like infections in the introduced bluestripe snapper Lutjanus kasmira in Hawaii. Dis Aquat Org 57:59-66

Yamaguti S (1968) Monogenetic trematodes of Hawaiian fishes, Vol 262. University of Hawaii Press, Honolulu, HI

Yamaguti S (1970) Digenetic trematodes of Hawaiian fishes. Keigaku Publishing, Tokyo

Yang T, Kritsky DC, Pan J (2007) Polylabris lingaoensis sp. $\mathrm{n}$. and Polylabris cf. mamaevi Ogawa et Egusa, 1980 (Monogenoidea: Microcotylidae) from perciform fishes in the Gulf of Tonkin, South China Sea. Folia Parasitol 54: $27-33$

Zhukov EV (1976) New monogenean species of the genus Haliotrema Johnston and Tiegs, 1922 from the Gulf of Mexico fishes of the family Lutianidae. In: Fauna, systematics and phylogeny of Monogenoidea. Proceedings of the Institute of Biology and Pedology of the Far-East. Science Centre of the Academy of Sciences of the USSR, New Series, Vol 35, Vladivostok, p 33-47 (in Russian)

Submitted: December 4, 2008; Accepted: April 3, 2009

Proofs received from author(s): May 29, 2009 